\title{
Alternaria tenuis alternata Antigen IgA Antibody Measurement
}

National Cancer Institute

\section{Source}

National Cancer Institute. Alternaria tenuis alternata Antigen IgA Antibody Measurement. NCl Thesaurus. Code C130151.

A measurement of the Alternaria tenuis alternata antigen IgA antibody in a biological specimen. 